\title{
Condensed tannin content and antioxidant activity of Hungarian sorghum varieties grown at Research Institute in Karcag
}

\author{
Róbert Nagy $^{1}$ - Erzsébet Szőllősi ${ }^{2}$ - Piroska Bíró Molnárné ${ }^{2}$ - Eszter Murányi ${ }^{3}$ - Róbert Czimbalmos ${ }^{3}$ - \\ Péter Sipos $^{2}$ \\ ${ }^{1}$ University of Debrecen, Faculty of Agricultural and Food Sciences and Environmental Management, Institute of Nutrition Science, \\ Debrecen \\ ${ }^{2}$ University of Debrecen, Faculty of Agricultural and Food Sciences and Environmental Management, Institute of Food Technology, \\ Debrecen \\ ${ }^{3}$ University of Debrecen, Institutes for Agricultural Research and Educational Farm, Karcag \\ nagy.robert@agr.unideb.hu
}

\begin{abstract}
SUMMARY
Cereal-based products are one of our main energy sources, and are consumed on a daily basis. One of the weaknesses of wheat based products is their low antioxidant content. Sorghum is a minor cereal, mostly consumed in Africa and Asia. Amongst other phenolic components it contains tannins, which are potent antioxidants and have other positive effect on human health, for example anti-tumor, anti-inflammatory and anti-viral/bacterial effect. We evaluated the tannin content (vanillin-HCL) and antioxidant capacity (DPPH) of sorghum varieties (Alföldi1, Zádor, Foehn, Albita, Albanus) grown in Hungary, with two type of agronomy technology. Red varieties especially Alföldil and Zádor had higher tannin contents than white varieties. The highest condensed tannin content was $1470 \pm 73 \mathrm{mg} 100 \mathrm{~g}^{-1}$ (Control, Alföldil),

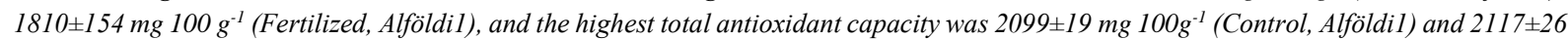
mg $100 \mathrm{~g}^{-1}$ (Fertilized, Alföldi) We found that sorghum type, variety and color influence their tannin and antioxidant contents in general.
\end{abstract}

Keywords: Sorghum bicolor, condensed tannins, antioxidants, cereals

\section{INTRODUCTION}

Cereals are major sources of nutrients in our diet. Besides their high carbohydrate content, which are our main energy source, they contain antioxidants and other biologically active compounds in significant amounts, for example tocopherols, phenolic acids and carotenoids (Akkoc et al., 2019). There are minor cereals, like millets, sorghum or teff which are grown in a smaller amount compared to wheat or maiz, and contains these compounds in greater amount, for example sorghum species. Sorghum (Sorghum bicolor, L.) is a tropical cereal, which comes from the hot and arid areas of Africa (Potgieter et al., 2016). Sorghum varieties are grown mainly in Africa and Central-Asia as food ingredients. In developed countries, like in the USA it is grown as an industrial plant, or animal feed (Girard et al., 2018). They are accustomed to extreme environmental circumstances and are resistant to drought and heat exposure (Józsa, 1976; Awika et al., 2017).

Antioxidants have important role living organism in the regulation of the level of free radicals. These reactive oxygen species (ROS) and reactive nitrogen species (RNS) can arise during biochemical reactions in the cells, and although they are needed in small amount, they can denature proteins, decrease enzyme activity and cause various chronicle diseases in humans as well (cardiovascular diseases, kidney damage) if produced in huge amount (Rasheed et al., 2019; Kunwar et al.; 2011). These antioxidative compounds like phenols, tocopherols, ascorbic acid or flavonoids play great role in the regulation of the amounts of these radicals, thus prevent illnesses related to free radicals.
Sorghum varieties are rich in such phenolic compounds, flavonoids, and minerals (Althwab et al., 2015; Girard et al., 2018; Wu et al., 2017). One of their main phenolic components are tannins., which have potent antioxidant activity, thanks to their many hydroxyl $(-\mathrm{OH})$ groups (Macáková et al., 2014). There are 2 major groups of tannins: hydrolysable tannins and condensed tannins. Hydrolysable tannins are polyols with gallic acid or ellagic acid-esters, while condensed tannins are polyhydroxi-flavan-3-ol oligomers or polymers, also called proanthocyanidins because their depolymerisation yields anthocyanidins (Koleckar et al., 2008; Macáková et al., 2014; Sekowski et al., 2020). Their major characteristics is chelating ability with metals proteins and lipids, thus reduce their bioavailability. Due to this property they are mostly excluded in animal feeding, but they can be used in human food industry as energy reducers. Tannins have many positive effect on human health, they prevent chronic diseases like cardiovascular diseases, or their anti-inflammatory effect, they also have a prooxidative enzyme inhibition effect, for example they inhibit nitric-oxid (NO) synthetase and xanthine oxidase activity. These enzymes are responsible for producing free radicals. (Kolarec et al., 2008; Macáková et al., 2014) The aim of this study was to analyse the antioxidant capacity and condensed tannin contents of 5 red and white sorghum varieties (Albita, Albanus, Alföldi1, Zádor, ES Foehn), and the evaluation of differences amongst the varieties and agronomic treatments. 


\section{MATERIALS AND METHODS}

The examined varieties were grown at the Institute for Agricultural Research and Educational Farm of University of Debrecen in Karcag, at the plot B1 (47.28957; 20.88794), in the year 2019. Crops were grown on 4 parcels per variety as replicates. Soil analysis were carried out in an accredited laboratory of Research Institute. The $\mathrm{pH}$ of soil was 5.1, its total salt content was $0.02 \mathrm{~m} / \mathrm{m} \%$, carbonated lime content was less than $0.05 \mathrm{~m} / \mathrm{m} \%$. Ammonium lactate soluble phosphorus peroxide $\left(\mathrm{P}_{2} \mathrm{O}_{5}\right)$ and potassium oxide $\left(\mathrm{K}_{2} \mathrm{O}\right)$ were 136 and $486 \mathrm{mg} \mathrm{kg}^{-1}$, respectively. Nitrate and nitrite derived nitrogen was $6.4 \mathrm{mg} \mathrm{kg}^{-1}$. The soil humus content was $3.4 \mathrm{~m} / \mathrm{m} \%$. Amongst meteorological properties mean precipitation and mean temperature (Table 1) were taken into consideration. There was an increased rainfall in May, compared to other months of the year. During the experiment 5 varieties of sorghum were investigated, white varieties (Albita, Albanus), and red varieties (Alföldi1, ES Foehn and Zádor). They were sown and cultivated in 2019 at $19.1 \mathrm{~m}^{2}$ parcel size. Beside control (Control), samples of one mineral fertilizer treatment with $60 \mathrm{~kg}$ ha $^{-1}$ (Fertilized) was evaluated in this study. The fertilizer used was $\mathrm{NH}_{4} \mathrm{NO}_{3}+\mathrm{CaMg}\left(\mathrm{CO}_{3}\right)_{2}$ with $27 \%$ nitrogen content. The samples were stored in textile sacks in storage room after harvest.

Table 1. Climatic data of 2019

\begin{tabular}{ccc}
\hline & $\begin{array}{c}\text { Precipitation } \\
(\mathbf{m m})\end{array}$ & $\begin{array}{c}\text { Average temperature } \\
\left({ }^{\mathbf{C}} \mathbf{C}\right)\end{array}$ \\
\hline January & 31.2 & -1 \\
February & 6.2 & 3.7 \\
March & 8.8 & 9 \\
April & 47.3 & 12.9 \\
May & 116.7 & 14.6 \\
June & 65.5 & 23.1 \\
July & 59.5 & 21.8 \\
August & 14.6 & 23.8 \\
September & 40.6 & 17.2 \\
October & 8.4 & 12.9 \\
November & 72.2 & 9.1 \\
December & 34.1 & 3.1 \\
\hline Total & $\mathbf{5 0 5 . 1}$ & \\
Mean & & $\mathbf{1 2 . 5}$ \\
\hline
\end{tabular}

\section{Sampling and measurements}

After homogenization, 150-160 g of grains were taken from each sack, and were peeled with a Satake peeler. The peeled kernels were milled with a roller mill. The flour and bran were weighted on an Ohaus analytical scale. Weighted samples were put in an airtight plastic bag ad were stored at $-20{ }^{\circ} \mathrm{C}$ before analysis. The antioxidant capacity, condensed tannin contents and dry matter contents were examined from sorghum brans and flours as a preliminary measurement.

\section{Determination of dry matter content}

Dry matter content was analyzed using a drying oven. Two gramms of brans and flours were measured in heat resistant cups and put in oven at $105^{\circ} \mathrm{C}$ for 3 hours. Samples were dried until reaching constant mass.

\section{Determination of antioxidant capacity}

For antioxidant measurement DPPH assay was used according to Blois (1958). Spectrophotometry measurement was made by a Spectrostar spectrophotometer. The DPPH is an artificial, purple free radical which is protonated by antioxidants, like tannins and phenols. Two mg of DPPH reagent was solved in $50 \mathrm{ml}$ methanol and stored in a dark bottle until measurement. Standards were made from $1.4 \mathrm{mg}$ $\mathrm{ml}^{-1}$ Trolox stock solution. Each standard point was made with $2 x$ methanol dilution. Samples were extracted with concentrated methanol (100\%), using ultrasonic water bath for $20 \mathrm{~min}$, homogenized and centrifuged at $3000 \mathrm{rpm}$ for $10 \mathrm{~min}$. The supernatant was saved and used later in analysis. Spectrophotometry analysis was concluded on a 96plate, the necessary reagents were added to the methanol extract and after incubation at $25^{\circ} \mathrm{C}$ and for $30 \mathrm{~min}$, measurement was carried out at $517 \mathrm{~nm}$. Results were given on dry matter (DM) base

\section{Determination of condensed tannin content}

Vanillin-HCL assay as colorimetric method was used for the determination of condensed tannin content of flours and brans. It based on the reaction of tannins with vanillin in the presence of acid. This reaction yields a red complex. Vanillin binds to the phenol rings. For standard (+) catechin was used. Vanillin (0.83 g) was solved in $20 \mathrm{ml}$ methanol, standards were prepared from $1.4 \mathrm{mg} \mathrm{ml}^{-1}$ stock solution, with twofold dilution. Samples were extracted with methanol (100\%) using an ultrasonic water bath for $20 \mathrm{~min}$. Samples were centrifuged at $3000 \mathrm{rpm}$ for $10 \mathrm{~min}$, and supernatants were saved. Reagents were added to the extract on a 96plate and was incubated at $25^{\circ} \mathrm{C}$ for $15 \mathrm{~min}$. Samples were analyzed at $500 \mathrm{~nm}$, using a Spectrostar spectrophotometer. Results were given on DM base.

\section{Statistical analysis}

Statistical evaluations were performed by Microsoft Excel. The effect of treatments were evaluated by $t$ probe after the homogeneity analysis of averages by Fisher's test.

\section{RESULTS AND DISCUSSION}

Figure 1 and Figure 2 show the condensed tannin (CT) contents of white and red sorghum varieties respectively. Statistically significant differences between the control and fertilized samples can be seen only in the case of Alföldil red sorghum variety $(\mathrm{p}<0.01)$. Among red sorghums Alföldil had the

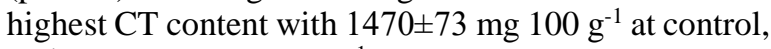
and $1810 \pm 154 \mathrm{mg} 100 \mathrm{~g}^{-1}$ for fertilized. Lowest values were found for ES Foehn, CT; they were at $148 \pm 14$ and 
$158 \pm 15 \mathrm{mg} 100 \mathrm{~g}^{-1}$. This is lower than values can be seen at white varieties. White varieties showed much lower values of CT content than red hybrids, except of ES Foehn, which showed a very low CT content despite being a red variety. CT contents varied depending on varieties and treatments in the case of white sorghum varieties, as can be seen in Figure 2. Albita (control) and Albanus (fertilized) had the highest values, $193 \pm 13$

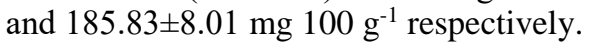

Figure 1. Condensed tannins values of red sorghum brans

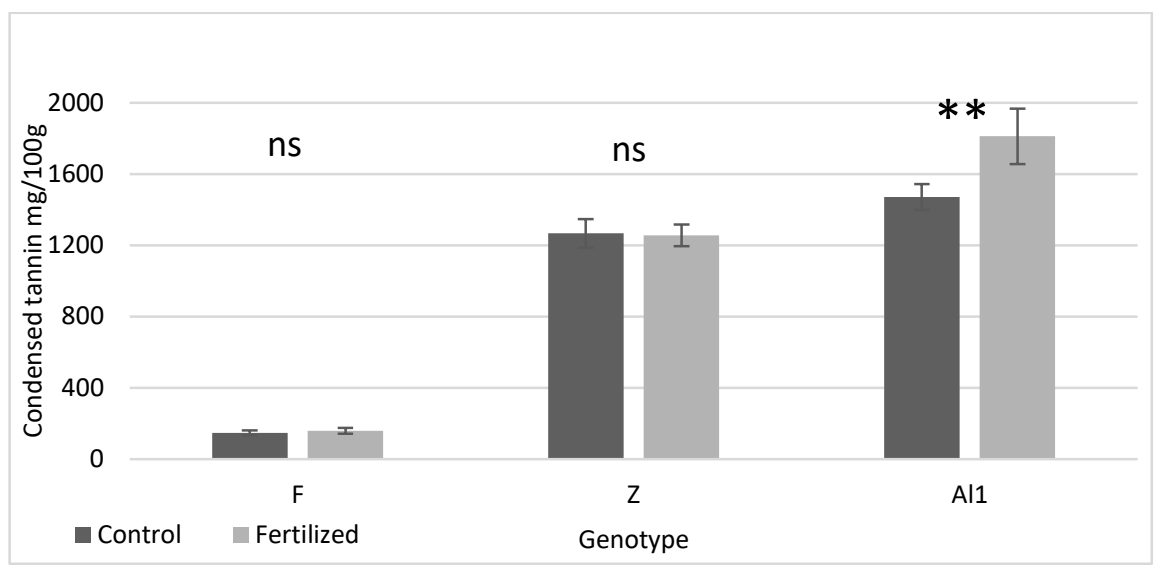

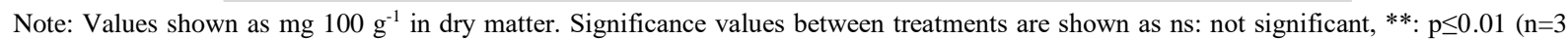
\pm s.e). F=Foehn, Z=Zádor, All= Alföldi1

Figure 2. Condensed tannins values of white sorghum brans

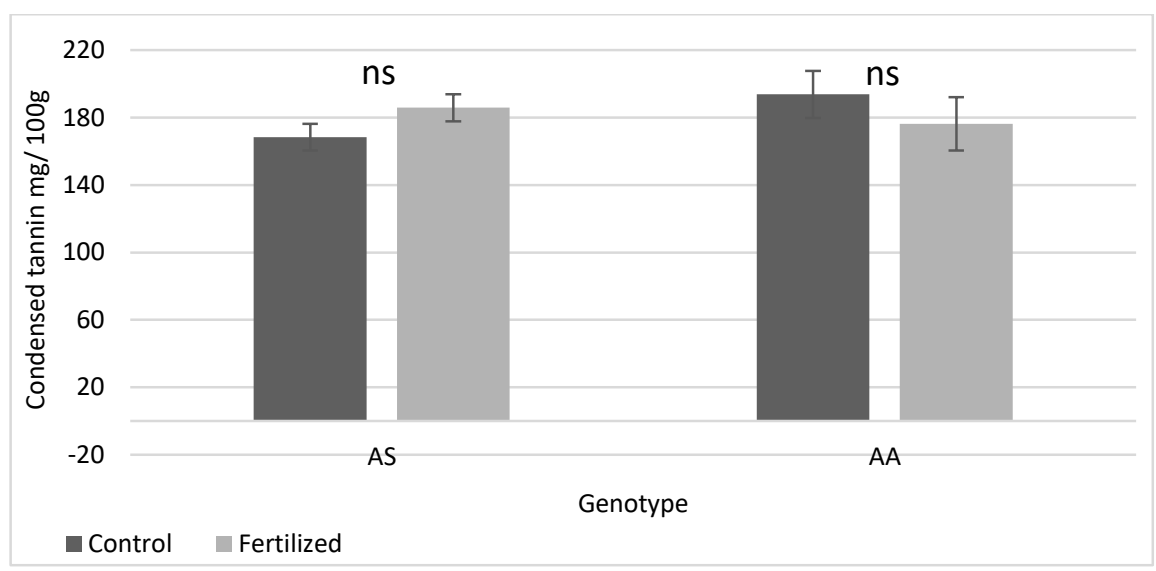

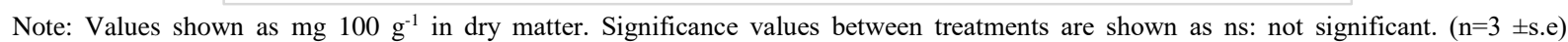
$\mathrm{AS}=$ Albanus, $\mathrm{AA}=$ Albita

Total antioxidant capacity values did not show significant differences $(\mathrm{p}<0.05)$ between treatments, but differed between sorghum varieties, and agronomy treatments (Control, Fertilized) as it is shown in Figure 3 and Figure 4. Red varieties had higher values than white varieties, which can be related with their higher CT contents.

Highest antioxidant capacity was measured in Alföldil sample at $2099 \pm 19$ and $2117 \pm 26 \mathrm{mg} 100 \mathrm{~g}^{-1}$. Among white varieties Albanus had a higher antioxidant capacity at $183 \pm 11$ and

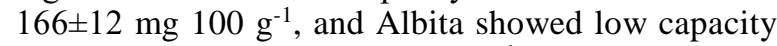
at $17 \pm 0.62$ and $16 \pm 1.12 \mathrm{mg} 100 \mathrm{~g}^{-1}$ respectively.
Brans aside, flours were also examined for CT content and DPPH activity. Except the flour of Albanus, there weren't statistically significant differences between treatments in the examined parameters. Albanus showed great difference at DPPH values for Control and Fertilized. Antioxidant capacity of Albanus flours were $31.94 \pm 4.16$ and $4.37 \pm 0.71 \mathrm{mg}$ $100 \mathrm{~g}^{-1}$ respectively. The CT content and DPPH activity of flours were very low and measured values were out of linear range. Results can be seen in Figure 5-8 and are indicative ones only. The CT content may come from residues of bran, while antioxidant activity values may come from accompanying components of carbohydrates or from the germ. 
Figure 3. DPPH values of red sorghum brans

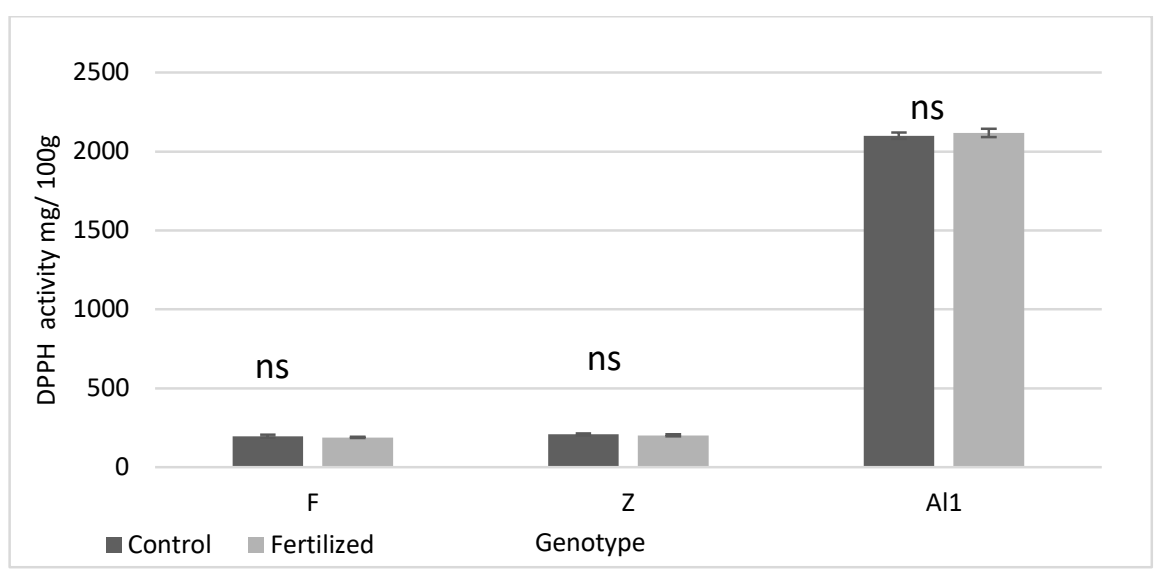

Note: Values shown as mg $100 \mathrm{~g}^{-1}$ in dry matter. Significance values between treatments are shown as ns: not significant. (n=3 \pm s.e). $F=F o e h n$, Z=Zádor, All= Alföldi 1

Figure 4. DPPH values of white sorghum brans

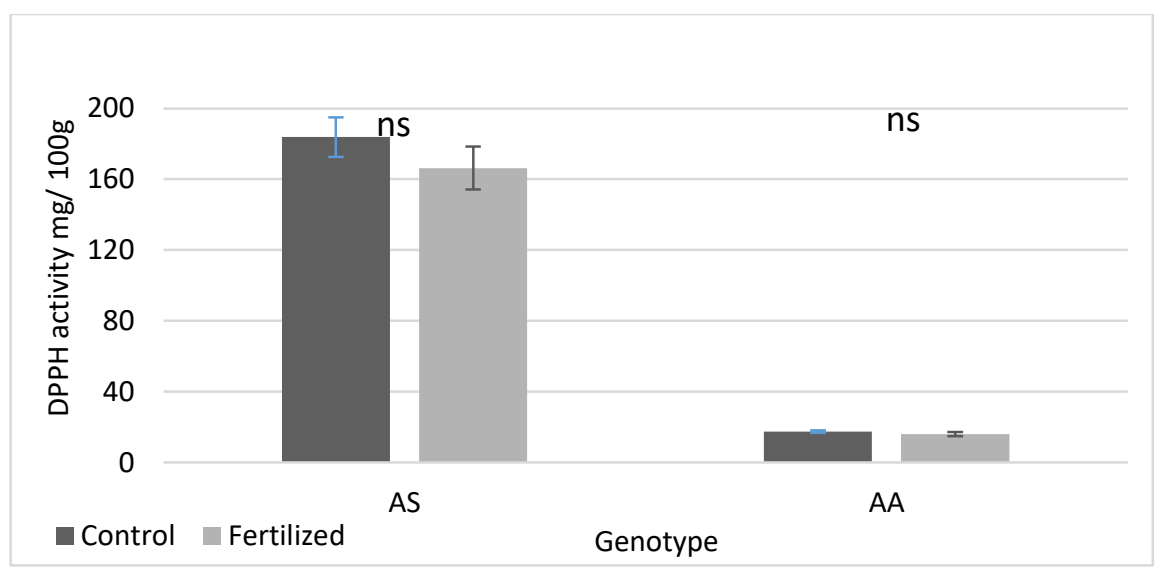

Note: Values shown as $\mathrm{mg} 100 \mathrm{~g}^{-1}$ in dry matter. Significance values between treatments are shown as ns: not significant. ( $\mathrm{n}=3 \pm \mathrm{s}$.e) AS=Albanus, AA=Albita

Figure 5. Condensed tannins values of red sorghum flours

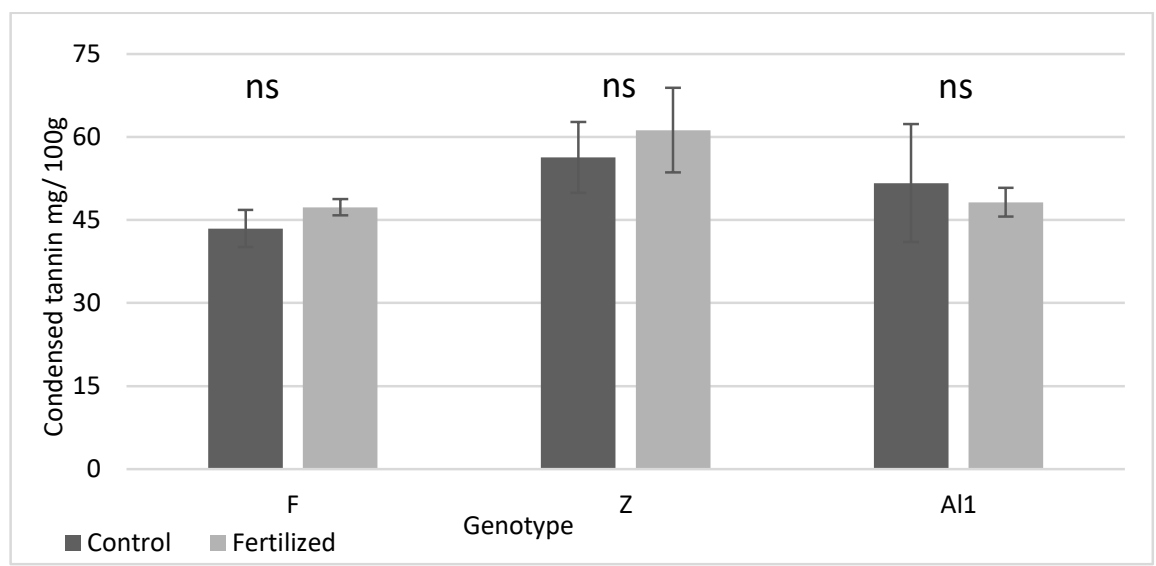

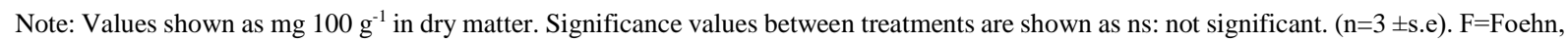
$\mathrm{Z}=$ Zádor, Al1 = Alföldi1 Results are out of linear range of used standards. 
Figure 6. Condensed tannins values of white sorghum flours

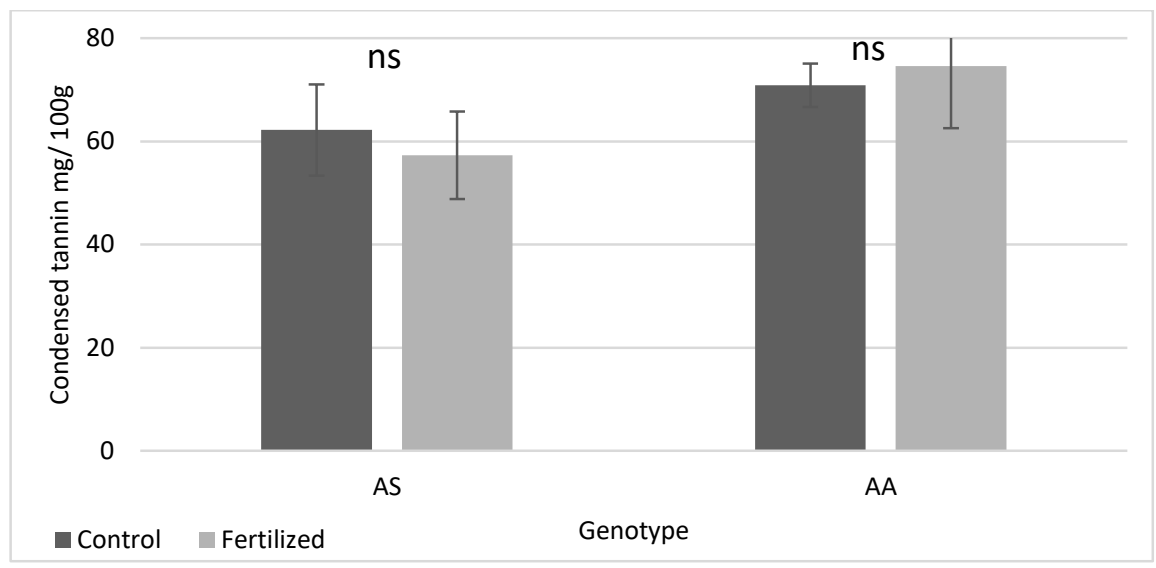

Note: Values shown as $\mathrm{mg} 100 \mathrm{~g}^{-1}$ in dry matter. Significance values between treatments are shown as ns: not significant. ( $\mathrm{n}=3 \pm \mathrm{s}$.e $)$ $\mathrm{AS}=\mathrm{Albanus}, \mathrm{AA}=\mathrm{Albita}$. Results are out of linear range of used standards.

Figure 7. DPPH values of red sorghum flours

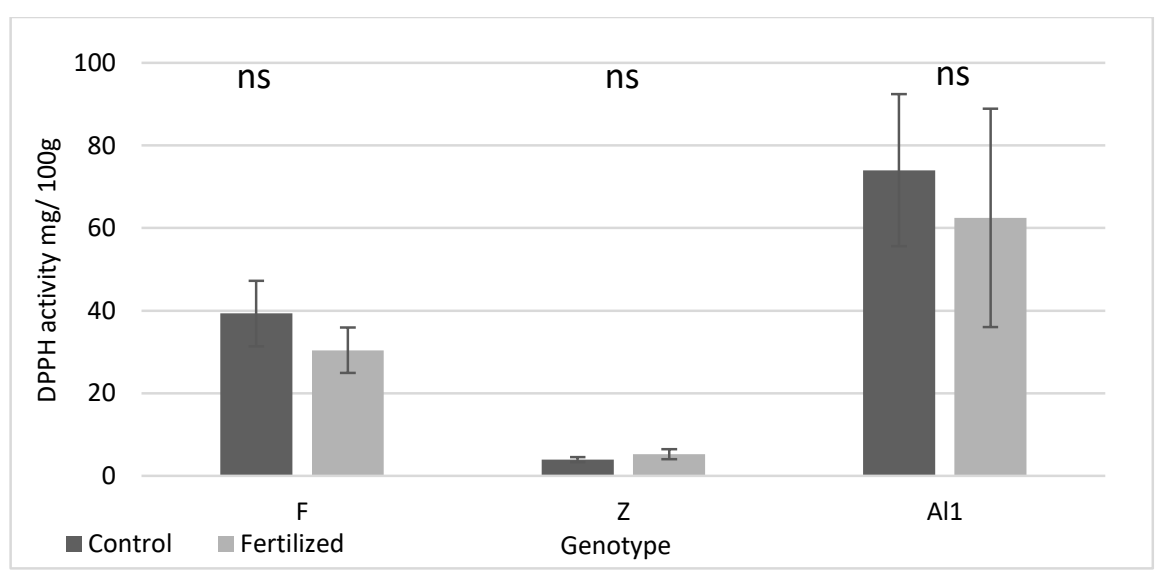

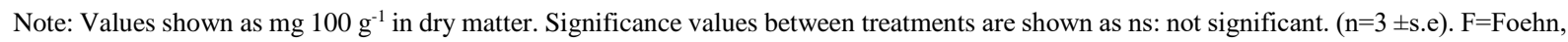
Z=Zádor, Al1= Alföldil Results are out of linear range of used standards.

\section{Figure 8. DPPH values of white sorghum flours}

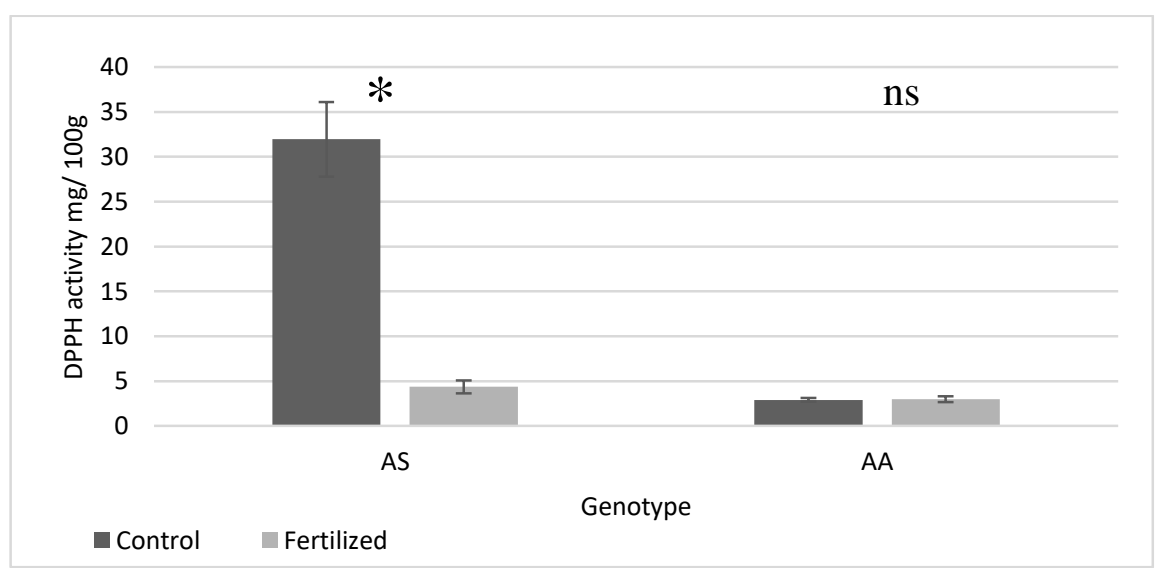

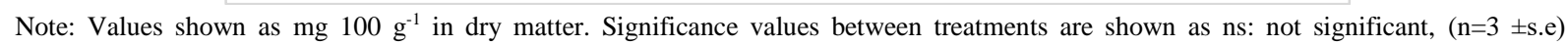
$\mathrm{AS}=\mathrm{Albanus}, \mathrm{AA}=\mathrm{Albita*}: \mathrm{p} \leq 0.05$. Results are out of linear range of used standards. 


\section{CONCLUSIONS}

After evaluating our results, it can be seen that there were clear differences between sorghum types and varieties in considering $\mathrm{CT}$ content and total antioxidant capacity. In general, we can say that grain color determines their phenolic compound contents and antioxidant capacity in general. Most red sorghum varieties had higher CT content and antioxidant activity than white ones. Also in each groups of sorghum varieties determined their tannin content. However, ES Foehn, despite being a red variety, had low CT content, and Zádor with a higher tannin value showed low antioxidant capacity. Other phenolic compounds, like flavonoids, phenolic acids could also contribute to the DPPH values. Much more and detailed measurements needed to get a clearer picture about these parameters.

\section{REFERENCES}

Akkoc, Y.-Lyubenova, L.-Grausguber, H.-Janovská, D.-Yazici, A.-Cakmak, I.-Gozuacik, D. (2019): Minor cereals exhibit superior antioxidant effects on human epithelial cells compared to common wheat cultivars. J. Cereal Sci. 85:143-152. DOI: https://doi.org/10.1016/j.jcs.2018.12.006

Althwab, S.-Carr, T.P.-Weller, C.L.-Dweikat, I.M -Schlegel, V. (2015): Advances in grain sorghum and its co - products as a human health promoting dietary system, Food Res. Int. 77:349359. DOI: https://doi.org/10.1016/j.foodres.2015.08.011

Awika, J.M. (2017): Sorghum: Its Unique Nutritional and Health Promoting Attributes. In Gluten - Free Ancient Grain: Cereals, Pseudocereals and Legumes covers grains that are not related to wheat. Foods for the $21^{\text {st }}$ Century. Taylor, J.R.N; Awika, J.M. Woodhead Publishing, Sawston, United Kingdom. pp. 21-54. DOI: https://doi.org/10.1016/B978-0-08-100866-9.00003-0

Blois, M.S. (1958): Antioxidant Determinations by the Use of a Stable Free Radical. Nature, 181: 1199-1200. DOI https://doi.org/10.1038/1811199a0

Girard, A.L.-Awika, J.M. (2018): Sorghum polyphenols and other bioactive components as functional and health promoting food ingredients, Journal Cereal Sci, 84:112-124. DOI: https://doi.org/10.1016/j.jcs.2018.10.009

Józsa, L. (1976): A takarmánycirok termesztése és felhasználása, Mezőgazdasági Kiadó, Budapest, 127p.

Koleckar, V.-Kubikova, K.-Rehakova, Z.-Kuca, K.-Jun, D.Jahodar, L.-Pletal, L. (2008): Condensed and Hydrolysable Tannins as Antioxidants Influencing the Health. Mini Rev Med Chem. 8:436-447. DOI: 10.2174/138955708784223486

Kunwar, A.-Priyadarsini, K.I. (2011): Free radicals, oxidative stress and importance of antioxidants in human health. J. Med. Allied. Sci. 1:53-60. DOI: 10.1007/s11746-998-0032-9
Macáková, K.-Kolečkář, V.-Cahlíková, L.-Chlebek, J.-Hoštálková, A.-Kuča, K.-Jun, D.-Opletal, L. (2014): Tannins and their Influence on Health. In Recent Advances in Medicinal Chemistry. Rahman, A.; Choudhary, M.I; Perry, G. Volume 1. Elsevier. Amsterdam, Hollandia. pp. 159-208. DOI: 10.2174/138955708784223486

Potgieter, A.B.-Lobell, D.B.- Hammer, G.L.-Jordan, R.-Davis, P.Brider, J. (2016): Yield trends under varying enviromental conditions for sorghum and wheat across Australia. Agric For Meteorol, 228-229: 276-285. DOI: https://doi.org/10.1016/j.agrformet.2016.07.004

Rasheed, A.-Azeez, R.F.A. (2019): A review on natural antioxidants. In Traditional and Complementary Medicine. 1st ed.; Mordeniz, C.; Intech Open, London, United Kingdom, pp. 75-99. DOI: 10.5772/intechopen.82636

Sekowski, S.-Olchowik-Grabarek, E.-Wieckowska, W.-Veiko, A.Oldak, L.-Gorodkiewicz, E.-Karamow, E.-Abdulladjanova, N.-Mavlyanov, S.-Lapshina, E.-Zavodnik, I.B.-Zamaraeva, M. (2020): Spectroscopic, Zeta - potential and Surface Plasmon Resonance analysis of interaction between potential anti - HIV tannins with different flexibility and human serum albumin. Colloids Surf. B. $194: 111175$. DOI: https://doi.org/10.1016/j.colsurfb.2020.111175

Surányi, B. (2013): Gazdasági növények a történelemben: A földmüveléstől a szántóföldi növénytermesztésig: egyetemi jegyzet, Debreceni Egyetem Kiadó, Debrecen, p. 160.

Wu, G.-Bennett, S.J.-Bornman, J.F.-Clarke, M.W.-Fang, Z.Johnson, S.K. (2017): Phenolic profile and content of sorghum grains under different irrigation managements, Food Res. Int. 97:347-355. DOI: 10.1016/j.foodres.2017.04.030. 